\title{
Prevalence of Indiscipline among Senior Secondary School Students and the Influnce on the Academic Achievement in Aguata Education Zone of Anambra State
}

\author{
Aloysius O. Ezeanolue, Stanley Nnorom
}

\begin{abstract}
Indiscipline among senior secondary school students has been problem in the achievement of educational objectives. The purpose of this study is to investigate the case of indiscipline among senior secondary school students. Descriptive survey research design was used. Three research questions and one hypothesis were formulated to guide this study. Cluster, stratified random sampling technique was used to select 8 schools that are 80 teachers and 160 students were used for the study. Structured questionnaire was the instrument used for data collection. The instrument with a reliability coefficient of 0.83 (students and 0.84 (teachers) using Cronbach Alfa was face-validated by 3 experts in measurement and evaluation. Data were analysed using mean, standard deviation and $z$ - test statistics. The result identified the cause of indiscipline and strategies for checking them. The result also indicates the significant difference, on the mean responses of students and that of the teachers on the strategies for reducing indiscipline. The educational implication with respect to parents, students, school administrators, Ministry of Education, researchers and teachers were discussed. Based on the result the researcher recommended as follows: regular motivation of teachers; effective supervision, regular workshop, seminars, and conferences; proper monitoring of children and peer they keep; enforcement of teaching of moral and religious instruction among others. The limitation and the suggestion for further study were highlighted.
\end{abstract}

Index Terms - Indiscipline, Teacher.

\section{INTRODUCTION}

Indiscipline is said to be as old as the time when men started to organize himself into society and consequently made law to order the affairs of men in a social set-up. In the Holy Scripture Cain exhibited some forms of indiscipline when he because of envy murdered his brother Abel in the. We have heard of people engaging in indiscipline behaviour on daily basis. Many of our students today especially those in senior secondary school exhibit various forms of indiscipline in form of juvenile delinquency. This could be in the form of robbery. These acts involve both adults and youths, the rate of indiscipline tends to increase in the modern world.

According to Ezegbe (1995), indiscipline is a state of order maintained by training and control, a particular system of regulation and exercise designed to train to proper conduct or action systematic training inflicted by way of correction and training. Johnson (2010), defines indiscipline as lack of control in behaviour of a group of people. Olusegun (2005) defined indiscipline as the improper training of the mind and body which can produce desired control necessary for an individual to perform the positive roles required for the achievement of organization or community goals and aspirations

Indiscipline persons refuse to accept the realities of life, they continue to day dream of a fantastic and fulfilled life without any attempt on their part to struggle to improve themselves in life. Children who are involved in indiscipline are not necessarily children from homes where there is no discipline or love; on the contrary, too much discipline and love could possibly have led some of such children to drug and other forms of indiscipline. Some children have become drug addicts as a result of their living and school environments. May be if such children were in a different environment they would not have known drugs (Odebunmi 1994).

Some studies identified some examples of indiscipline. Examples of indiscipline as cited by Eneastator and Azubuike (2009) are cheating, examination malpractice, dishonesty, lateness to school, stealing, shabby dressing, absenteeism, truancy, loitering, sex scandals, insulting /assaulting.

"Today, as intolerance, impatience and violence which are fruits of indiscipline has eaten deep into all facets of life of Nigerians including Senior High School students" Daily Graphic, 7th March, (2002:3). According to Maphosa andMammen (2011), basic schools of today are noted for disrespecting authorities, going to school late, fighting among themselves, refusing to do homework and dressing indecently. Some of the pupils/students go to the extent of vandalizing school property and assaulting teachers for taking disciplinary actions against them or a colleague. Pre-marital sex, armed robbery, drug abuse, drunkenness and smoking of marijuana in Nigeria have been reported to be prevalent among basic schools in the country Director-General, Asare and Adzrolo (2013).The causes of these acts of indiscipline among pupils/students as stated by teachers and parents were attributed to the home and school environment, teacher related factors in addition to the other emerging phenomenon outside our Nigeria culture. Intolerance and indiscipline behaviour brings about disorder, destruction and anxiety among the pupils. Indiscipline behaviours therefore do not 
create conducive environment for learning but leads to poor academic work. There is a general notion that standard of education in Nigeria is falling and this has been attributed to internal, external, political constraints and human factors Inglehartand Welzel, (2005). Indiscipline behaviours could be one of the human factors that might have contributed to the falling standards of education. Despite the threat and negative impact of indiscipline on students' learning, few researches have been done to assess the effects of indiscipline on students' academic performance in schools within some State in Nigeria.

Asiayi (2012), in his study investigates indiscipline in secondary schools in Nigeria with the purpose of finding out the common types, it causes and possible solution. The study employed descriptive survey research design. Four research questions were raised and answered while two hypotheses were formulated and tested. In his findings, he revealed the common types of indiscipline as insubordination to school teachers and prefects, cases relating to the collective misbehaviour of students and cases relating to poor habits.

Sarumi and Okoji (2010), in their study examined the causes and effects of indiscipline on academic performance of female secondary school students in Owerri North Local Government Area of Imo State of Nigeria. The hypotheses raised were tested 0.05 level of significance. The result revealed that there is a significant effect of peer group on indiscipline. There is a significance effect of parents influence on discipline. A descriptive survey research design was adopted using questionnaire as the main instrument. Based on the findings, it was recommended among things, that parents should give their children proper upbringing, teachers should be committed to their duties and be upright as students looks up to them as role models.

The causes of indiscipline identified in some studies have not been verified with a research investigation, particularly in the researcher area of study to the best of the researchers' knowledge. Some studies have also shown that the cases of indiscipline have been on the increases in the school system, in recent time. Based on this background, the researcher have developed interest in carrying out a research aimed at investigation the causes of indiscipline among senior secondary schools in Aguata Local Government Area, Anambra State.

\section{Statement OF THE Problem}

The problem of indiscipline among secondary school students in Aguata Local Government Area of Anambra State poses a threat to the attainment of educational objectives. This issue had attracted a lot of attention and has elicited comments from many stakeholders in education. There are different types of indiscipline observable in schools by students these days. The undesirable behaviours include truancy; fighting, stealing, absenteeism, and sexual abuses etc. Questions now arise; what are the causes of indiscipline? What are the strategies for checking indiscipline in the school system? The researcher is interested in the answers to these questions. It is against this background that the statement of the problem of this study is based.

The study is concerned with the investigation of the causes of indiscipline among students in secondary schools and how it affects the academic performance of the child; the danger of indiscipline in schools as well as its influence on the child cannot be over emphasized. The school environment, teachers, parents, society, peer groups, have their individuals and collective role.

\section{Purpose of the Study}

The general purpose of this study was to investigate indiscipline among senior secondary schools students.

Specifically the researcher intended to do the following:

> Determine the causes of indiscipline among senior secondary school students.

Identify the strategies for checking indiscipline in senior secondary schools.

Determine the extent teachers and students agree on the strategies for checking indiscipline.

To investigate whether parents are in a way, either knowingly or unknowingly in school.

$>$ To determine whether the nature of the school administration has influence the indiscipline exhibited by the students.

To investigate whether the socio-economic has any influence on indiscipline among secondary school students.

\section{SCOPE OF THE STUDY}

The study is limited to senior public and mission secondary schools in Aguata Local Government Area of Anambra State. The study covered the causes of indiscipline among senior secondary school students. This study is limited to ten secondary schools (public and mission) out of the entire twenty-one secondary school in Aguata Local Government Area of Anambra State.

\section{Research Questions}

This study is guided by the following research questions:

1. What are the causes of indiscipline among senior secondary school students?

2. What are the strategies for checking indiscipline in the senior secondary schools?

3. To what extent do teachers and students agrees on the strategies for checking indiscipline?

4. Is there any different between indiscipline and the academic performance of students in schools.

5. Does socio-economic background of parents encourage students' indiscipline in schools?

6. Does the nature of school administration 
encourage indiscipline among students in the school?

7. Do too many rules and regulations encourage indiscipline in school?

\section{Hypothesis of the Study}

$\mathrm{H}_{0}$ : There is no significance difference on the mean ratings of teachers and students on the strategies for checking indiscipline in the school system.

\section{RESEARCH METHODOLOGY}

The descriptive survey design was used for the study. The area of the study was Aguata Local Government Area of Anambra State. Aguata Local Government is located in Anambra South senatorial district. It has fourteen (14) towns .Almost each of these towns could boast of at least one school. The accessible population of the study consists of twenty-nine (29) schools both public schools and mission schools that is (20) public schools and (9) mission schools with the total number of five hundred and twelve teachers (512) and all the senior secondary two (SS2) students with the total number of nine hundred and two students (902) both in public and mission schools. The SS2 students were chosen for the study because the school authorities do not permit the use of the SS3 students who were preparing for their external examinations. The SS1 students were not use because they were new in the school.

A stratified sampling was used to stratify the schools into public and mission secondary schools and their teachers and students. After stratifying the schools into different strata, simple random sampling techniques was used to sample the schools, teachers and students from each stratum. All the secondary schools owned by the government are classified as public schools while all the secondary schools owned by the church are classified as mission schools.

The total number of sampled schools were eight (8) that is

Table 1: Mean and standard deviation of the responses of teachers and students on causes of indiscipline in senior secondary schools.

\begin{tabular}{|c|c|c|c|c|c|c|c|c|c|}
\hline & & \multicolumn{3}{|c|}{ Teachers } & & \multicolumn{3}{|c|}{ Students } & \\
\hline $\mathbf{S} / \mathbf{N}$ & Items & $\mathbf{N}$ & $\mathbf{X}$ & SD & Decision & $\mathbf{N}$ & $\mathbf{X}$ & SD & Decision \\
\hline 1 & Poor parental up bringing & 80 & 35 & 0.68 & Accept & 160 & 3.2 & 0.09 & Accept \\
\hline 2 & $\begin{array}{l}\text { Improper moral up-bringing of the } \\
\text { children }\end{array}$ & 80 & 3.5 & 1.1 & Accept & 160 & 2.8 & 0.8 & Accept \\
\hline 3 & Peer group influence & 80 & 3.2 & 11 & Accept & 160 & 2.7 & 1.10 & Accept \\
\hline 4 & $\begin{array}{l}\text { Parental attitude towards the } \\
\text { children }\end{array}$ & 80 & 3.1 & 0.92 & Accept & 160 & 2.6 & 1.09 & Accept \\
\hline 5 & Influence of the environment & 80 & 2.6 & 0.89 & Accept & 160 & 2.7 & 1.08 & Accept \\
\hline 6 & $\begin{array}{l}\text { Inadequate supervision of teaching } \\
\text { and learning }\end{array}$ & 80 & 2.1 & 0.97 & Accept & 160 & 2.4 & 1.64 & Reject \\
\hline
\end{tabular}

four public schools and four mission schools with the total number of seventy-one (80) teachers and one hundred and sixty students (160) from public and mission senior secondary schools in Aguata Local Government Area of Anambra State.

Structured questionnaire was the instrument used for data collection. The instrument was a four-point like-type questionnaire made up of twenty (20) items. The scale points are Strongly Agree (SA), Agree (A), Disagree (D) and

Strongly Disagree (SD). The respondents were instructed to indicate with a tick $(\sqrt{ })$ their degree of agreement or disagreement on the items. A letter for the respondents was attached to each questionnaire. The instrument has two sections: section A-personal data and section B-the items of the instrument. The instrument was validated by three experts in educational measurement and evaluation. The reliability of the instrument ( 0.83 for students and 0.84 for teachers) was established using Cronbach coefficient alpha method. Three research question and one hypothesis were also formulated to guide the study

The data collected were analyzed using mean and standard deviation to answer the research questions. Z-test statistics was used, while the decision rule is that if $\mathrm{z}$-calculated is greater than z-critical we reject the null hypothesis and uphold the alternative hypothesis.

\section{RESULTS}

Research Question 1: What is the causes of indiscipline among senior secondary school students? 
Prevalence of Indiscipline among Senior Secondary School Students and the Influnce on the Academic Achievement in Aguata Education Zone of Anambra State

\begin{tabular}{|c|l|l|l|l|l|l|l|l|c|}
\hline 7 & $\begin{array}{l}\text { Inadequate provision of } \\
\text { instructional facilities in the school }\end{array}$ & & 2.1 & 0.97 & Reject & $\mathbf{1 6 0}$ & 2.2 & 1.16 & Reject \\
\hline 8 & \begin{tabular}{l} 
Influence of western culture \\
\hline
\end{tabular} & $\mathbf{8 0}$ & 2.4 & 1.14 & Reject & $\mathbf{1 6 0}$ & 3.2 & 1.3 & Accept \\
\hline 10 & $\begin{array}{l}\text { Inadequate qualified teachers } \\
\text { Inadequate motivation of } \\
\text { classroom teachers }\end{array}$ & $\mathbf{8 0}$ & 2.6 & 0.92 & Accept & $\mathbf{1 6 0}$ & 2.9 & 1.75 & Accept \\
\hline 11 & $\begin{array}{l}\text { High level of corruption in the } \\
\text { society }\end{array}$ & $\mathbf{8 0}$ & 3.4 & 0.91 & Accept & $\mathbf{1 6 0}$ & 2.31 & 0.11 & Reject \\
\hline 12 & $\begin{array}{l}\text { Inadequate security of the school } \\
\text { environment }\end{array}$ & $\mathbf{8 0}$ & 2.6 & 1.02 & Accept & $\mathbf{1 6 0}$ & 2.2 & 1.2 & Reject \\
\hline \begin{tabular}{l} 
Grand Mean \\
\hline
\end{tabular} & & $\mathbf{2 . 9 1}$ & $\mathbf{0 . 9 4}$ & & & $\mathbf{2 . 6 5}$ & $\mathbf{0 . 9 4}$ & \\
\hline
\end{tabular}

Table 2: Summary of mean and standard deviation of responses of students and teachers on causes of indiscipline

\begin{tabular}{|l|l|l|l|}
\hline Variable & N & X & S.D \\
\hline Students & 160 & 2.65 & 0.94 \\
\hline Teachers & 80 & 2.91 & 0.94 \\
\hline
\end{tabular}

The result on table one above indicates the following items as the causes of indiscipline: Item 1, 2, 3,4,5,9, and 10 .

From the results of the study the following are the causes of indiscipline: poor parental up-bring; improper moral up-bringing of the children; peer group influence; parents' attitude towards their children; influence of the environment; inadequate qualified teachers and inadequate motivation of classroom teachers.

Inadequate provision of infrastructural facilities in the schools (item7) was rejected by the students and the teachers as the causes of indiscipline in senior secondary schools.
These were rejected by the students and accepted by the teachers as the causes of indiscipline: (item6): inadequate supervision of teaching and learning: (item 11): high level of corruption in the society; and (item 12) inadequate security of the school environment.

Influence of western culture (item 8) was rejected by teachers and accepted by students as a causes of indiscipline in secondary schools.

Research Question 2: What are the strategies for checking indiscipline in the senior secondary schools?

Table 3: Mean and standard deviation of the responses of teachers and students on strategies for checking indiscipline in senior secondary schools.

\begin{tabular}{|c|c|c|c|c|c|c|c|c|c|}
\hline & & \multicolumn{3}{|c|}{ Teaches } & & \multicolumn{3}{|c|}{ Students } & \multirow[b]{2}{*}{ Decision } \\
\hline $\mathbf{S} / \mathbf{N}$ & Items & $\mathbf{N}$ & $\mathbf{X}$ & SD & Decision & $\mathbf{N}$ & $\mathbf{X}$ & SD & \\
\hline 13 & Effective teaching and learning & 80 & 3.2 & 0.80 & Accept & 160 & 3.1 & 1.2 & Accept \\
\hline 14 & Use of corporal punishment & 80 & 2.8 & 0.92 & Accept & 160 & 2.8 & 1.0 & Accept \\
\hline 15 & $\begin{array}{l}\text { Effective monitoring of teaching } \\
\text { and learning }\end{array}$ & 80 & 3.1 & 0.82 & Accept & 160 & 2.7 & 0.95 & Accept \\
\hline 16 & $\begin{array}{l}\text { Enforcing the teaching of moral } \\
\text { instructions }\end{array}$ & 80 & 3.4 & 0.3 & Accept & 160 & 2.6 & 1.05 & Accept \\
\hline 17 & $\begin{array}{l}\text { Engagement of students in social } \\
\text { activities }\end{array}$ & 80 & 2.8 & 0.2 & Accept & 160 & 2.6 & 0.98 & Accept \\
\hline 18 & $\begin{array}{l}\text { Enforcement of school rules and } \\
\text { regulations }\end{array}$ & 80 & 3.4 & 0.68 & Accept & 160 & 2.6 & 0.11 & Reject \\
\hline
\end{tabular}




\begin{tabular}{|c|l|c|c|c|c|c|c|c|c|}
\hline 19 & $\begin{array}{l}\text { Effective guidance and counselling } \\
\text { services }\end{array}$ & 3.5 & 0.59 & Reject & $\mathbf{1 6 0}$ & 2.6 & 0.06 & Reject \\
\hline 20 & $\begin{array}{l}\text { Allowing teachers free hand to } \\
\text { discipline students }\end{array}$ & $\mathbf{8 0}$ & 2.8 & 0.83 & Reject & $\mathbf{1 6 0}$ & 2.5 & 0.09 & Accept \\
\hline 21 & $\begin{array}{l}\text { Effective use of school } \\
\text { functionaries }\end{array}$ & $\mathbf{8 0}$ & 2.6 & 0.86 & Accept & $\mathbf{1 6 0}$ & 2.5 & 0.09 & Accept \\
\hline $\begin{array}{l}\text { Participating of students in } \\
\text { extracurricular activities }\end{array}$ & $\mathbf{8 0}$ & 2.6 & 0.89 & Accept & $\mathbf{1 6 0}$ & 2.7 & 1.07 & Accept \\
\hline 23 & $\begin{array}{l}\text { Teachers showing good example to } \\
\text { students }\end{array}$ & $\mathbf{8 0}$ & 3.6 & 0.69 & Accept & $\mathbf{1 6 0}$ & 2.7 & 1.11 & Reject \\
\hline $\begin{array}{l}\text { Encouraging of parents, teachers } \\
\text { interaction }\end{array}$ & $\mathbf{8 0}$ & 3.2 & 0.65 & Accept & $\mathbf{1 6 0}$ & 2.4 & 1.05 & Reject \\
\hline 25 & $\begin{array}{l}\text { Encouraging boarding system in } \\
\text { the school system }\end{array}$ & $\mathbf{8 0}$ & 2.3 & 0.92 & Reject & $\mathbf{1 6 0}$ & 2.0 & 1.2 & Reject \\
\hline Grand Mean & & $\mathbf{3 . 0 3}$ & $\mathbf{0 . 6 9}$ & & & $\mathbf{2 . 6 1}$ & $\mathbf{0 . 8 4}$ & \\
\hline
\end{tabular}

Table 4: Summary of mean and standard deviation of responses of students and teachers on strategies for checking indiscipline.

\begin{tabular}{|l|l|l|l|}
\hline Variable & N & X & S.D \\
\hline Students & 160 & 2.61 & 0.84 \\
\hline Teachers & 80 & 3.03 & 0.69 \\
\hline
\end{tabular}

Data on table 3 above has identified all the items on the table as the strategies for reducing indiscipline with the exception of items 24 and 25.

From the results the following are therefore the strategies for reducing indiscipline: Effective teaching and learning; use of corporal punishment; effective monitoring of teaching and learning; enforcing the teaching of moral instructions; effective guidance and counselling services; allowing teachers free hand to discipline students; effective use of school functionaries; participation of students in extracurricular activities and teachers showing good example to students.

Research Question 3: To what extent do the responses of students and teachers agree on the strategies for checking indiscipline in senior secondary school?

Table 5: Z-test analysis on the mean responses of students and teachers on the strategies for reducing indiscipline in the school system.

\begin{tabular}{|c|c|c|c|c|c|c|c|c|}
\hline Variable & $\mathbf{N}$ & $\mathbf{X}$ & S.D & DF & al $^{\text {Z-c }}$ & Z-crit & $\begin{array}{cc}\text { Level } & \text { of } \\
\text { Significance } & \\
\end{array}$ & Decision \\
\hline Teachers & 80 & 3.03 & 0.73 & \multirow{3}{*}{238} & \multirow{3}{*}{$48^{1.30}$} & \multirow{3}{*}{1.960} & \multirow{3}{*}{0.05} & \multirow{3}{*}{$\begin{array}{l}\text { Significan } \\
\text { ce }\end{array}$} \\
\hline Students & $0^{16}$ & 2.60 & 0.77 & & & & & \\
\hline Total & $0^{24}$ & & & & & & & \\
\hline
\end{tabular}

As shown on table 5, the z-calculated (1.3048) is less than Z-critical (1.960). The hypothesis is therefore significance at 0.05 level of significant and 2.38 degree of freedom. Hypothesis is therefore accepted. This implies that there is no significant different on the mean responses of teachers and
As shown on the table 3, item 24 which is encouragement of parents, teachers' interaction was rejected by students and accepted by teachers. Item 25 which is encouraging boarding system in the school system was rejected by both teachers and students, as a strategy for checking indiscipline in senior secondary schools. As indicated on table 4; the mean of student's responses on the strategies for checking indiscipline is 2.61 with S.D of 0.84 . That of teachers is 3.03 with S.D of 0.19 . Mean responses of teachers is therefore a little higher than that of students. Both teachers and students identified item 13-23 as accepted strategies for checking indiscipline.

\section{Hypothesis}

There is no significant different in the mean ratings of students and that of the teachers on the strategies for reducing indiscipline in the school system. that of the students on the strategies used in reducing indiscipline in school system.

\section{Discussion of Findings}

This was done using the following sub-headings: causes of indiscipline, strategies for reducing indiscipline and the 
extent to which the teachers and students agree on the strategies for checking indiscipline

\section{Causes of Indiscipline}

The findings revealed that poor parental upbringing, improper moral upbringing, peer group influence, parents' attitude towards the children, influence of the environment, inadequate qualified teachers and inadequate motivation of classroom teachers.

The result of the study agrees with that of Sarumi and Okoji (2010), Lud and Ojedapo (2009). From their findings, peer group influence, parental attitude were found to be responsible for indiscipline among secondary school students.

\section{Strategies for Checking Indiscipline}

The findings revealed the following strategies as effective for checking indiscipline: effective teaching and learning, use of corporal punishment, effective monitoring of teaching and learning, enforcing the teaching of moral instructions, effective guidance and counselling services, allowing teachers free hand to discipline students, effective use of school functionaries, participation of students in extracurricular activities and teachers showing good examples to students.

The result of this study agrees with that of Asiayi (2012). From this finding, moral leadership and education, and societal orientation were found to be effective for checking indiscipline in senior secondary schools.

The Extent to which Students and Teachers Agree on

\section{the Strategies for Reducing Indiscipline}

The findings of the study revealed that items 24 which is encouragement of parents' teachers' interaction was rejected by students and accepted by teachers. While item 25 which is encouraging boarding system in the school system was rejected by both teachers and students as a strategies for checking indiscipline in senior secondary schools.

The mean of students' responses on the strategies for checking indiscipline is 2.61 with standard deviation (S.d) of 0.84 while that of teachers is 3.03 with S.d of 0.64. Mean responses of teachers is therefore a little higher than that of students. Both teachers and students identified items 13-23 as accepted strategies for checking indiscipline.

The result of the study agrees with that of Okeke (2004), who discovered that lack of corporal punishment, moral aspect of religion and irregular payment of teachers' salaries constituted the major problems of indiscipline in schools.

\section{CONCLUSION}

From the findings of the study, the following conclusion was drawn: causes of indiscipline are as follows: poor parental; up-bringing, peer group influence, parents attitudes, influence of the environment, improper moral up-bringing, inadequate qualified teachers and inadequate motivation of classroom teachers.

From the result of the study, the strategies for checking indiscipline are as follows: effective teaching and learning, use of corporal punishment, effective monitoring of teaching and learning, enforcing the teaching of moral instructions, engagement of students in social activities, enforcement of school rules and regulations, effective guidance and counselling services, allowing teachers free hand to discipline students, effective use of school functionaries, participation of students in extracurricular activities and teachers showing good examples of students.

There is a significant difference on the mean responses of students and that of teachers on the strategies for checking indiscipline in senior secondary schools.

\section{Implication of the Study}

The result of the study has far reaching implications for parents, students, school administrators, ministry of Education, researchers and classroom teachers.

1. The results of this study have implications for parents. The result identified poor parent up-bringing as causes of indiscipline among students. The implication is that the result has created awareness on need for parents to take good care of their children. It also shows a strong need for encouragement of parents' teachers association (P. T. A) as to help parents for their children.

2. The findings have implication for students. Student's engagements in social activities as well as participation in extracurricular activities were identified in the study as strategies for reducing indiscipline. The implication of this is that the findings will rekindle interest in encouraging students to engage in extracurricular and social activities.

3. School administrators: The indicates that effective supervision, effective teaching and learning, enforcement of school rules and regulations are very good strategies for reducing indiscipline. The implication of this result is that it has created strong need for school administrators to make effective use of such strategies in school management to help reduce indiscipline.

4. The results of the study have implications for the ministry of education. For instance: inadequate qualified teachers, poor infrastructure, inadequate supervision of teacher and others were identified as causes of indiscipline. The implication is that the findings will create awareness and motivate ministry of education to recruit and post teachers to schools as well as find ways of addressing the other problems identified.

5. The results have implication for future researchers: The findings will motivate interest in researchers in the area of indiscipline. Data on the study will provide a resources base for researchers in the area.

6. The result of the study has implications for classroom teachers. It creates awareness on the causes and strategies for checking indiscipline. The result identified uses of corporal punishment and effective teaching and learning as good strategies for reducing indiscipline. The implication is that the result will create consciousness among teachers on the need for effective use of the strategies to address the problems. 


\section{RECOMMENDATIONS}

Based on the result of this study, the following recommendations were made:

There should be regular motivation of classroom teachers. For example, through regular payment of their salaries, allowances and other entitlement.

Effective supervision of teaching and learning should be encouraged in the school system. Findings of this study identified this as strong strategy for reducing indiscipline. Recruitment and posting of qualified teachers to all school is important. Inadequate qualified teachers have been identified as a cause of indiscipline.

Seminars, workshops, in-service training and others should be organized by the Ministry of Education to up data teachers knowledge as well as guiding both teachers' and students' behaviour in schools. Effective teaching and learning was identified as a strategy for checking indiscipline in school system.

Parents should be encouraged to spend time with their children before and after school periods. This will enhance the children's moral up-bringing and academic performance.

a. The result of this study identified improper moral up-bringing as a cause of indiscipline.

b. Parents should monitor their children on the types of films they watch and friends they keep.

c. Parents try their best to know the peer group members of their children and try to control and direct them on time to avoid indulgence in indiscipline among senior schools students.

The teaching of moral and religious education should be enforced and made to be part of the school assessment processes. This has been identified in this study as a good strategy for reducing indiscipline.

\section{LIMITATION OF THE STUDY}

The researchers found it difficult to convince some of school principals and form teachers to allow us to distribute questionnaires to the students and teachers in their schools.

Inability to cover all schools in Aguata Local Government Area of Anambra State due to time and financial constraints.

The researchers would have liked to use both public and private schools in the study to increase the generalizability of the findings. However, financial Constraints limited the study to only public schools in the study area.

\section{Suggestions for Further Studies}

The researchers suggest the following areas for further study:

1. Causes of indiscipline among senior secondary school students in Orumba north and south Local Government Area of Anambra State.

2. Identifying the strategies for checking indiscipline in senior secondary school in Owerri Educational Zone in Imo State.

3. Causes of indiscipline among students in Federal college of education umunzeAnambra State.

\section{REFERENCES}

[1] Asare, K.B and Adzrolo, B. (2013). Lecturers' students'and administrations' perception of discipline in the faculty of education University of cape coast,

[2] Ghana. SAGE Open, April-June, 1-8.

[3] Asiyia, R. I. (2012). Indiscipline in Nigeria Secondary Schools. African journal of education and technology (1) Abraka www.sachajournals.com.

[4] Eneasator, G. O \&Azubuike, K. (2009). Educational Adminstration and Supervision. (Revisited Edition). Onitsha: Ever Standard.

[5] Ezegbe, M. O. (1995). Curbing indiscipline in Nigeria secondary schools through Junior secondary school studies education. In F. O. M. Arinze Reading in Secondary Education. Onitsha: Hornbill Publishers

[6] Johnson, H. B. (2010). The effect of indiscipline on the achievement of secondary school goals. New York: Harper and Row publishers.

[7] Okeke, V. (2004). Problems of indiscipline in River State. Owerri: Imo State.

[8] Olusegun, R. O (2005) Brief survey of indiscipline in schools. Ibadan: Heinemann Books.

[9] Sarumi, A. \&Okoji, O. (2010). Indiscipline among the female secondary school students in selected rural community of River State. Journal of Education and practice. www.iiste.org. 